
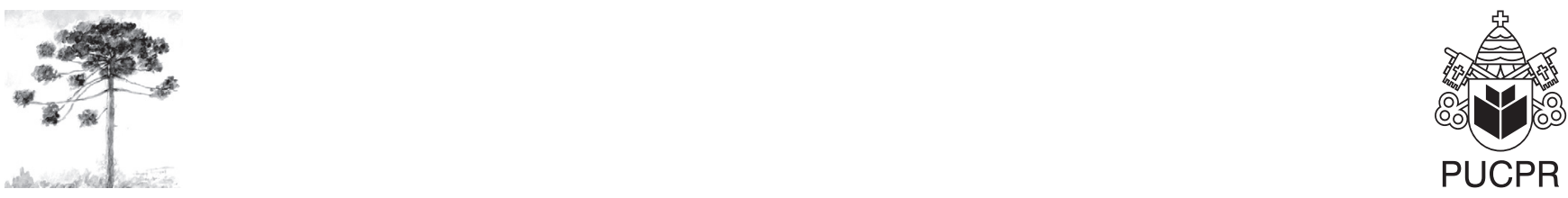

PUCPR

\title{
Evaluation of anticholinesterasic substances in cigarettes manufactured in Brazil through a human butyrylcholinesterase activity inhibition method
}

\author{
Pesquisa de substâncias anticolinesterásicas presentes em cigarros manufaturados \\ no Brasil por meio de um método de inibição da butirilcolinesterase bumana
}

\author{
Mariana Hiromi Azuma ${ }^{[a]}$, Marina de Almeida ${ }^{[a]}$, Sérgio Eduardo Fontoura-da-Silva ${ }^{[b]}$, \\ Thais Campos Peliky ${ }^{[a]}$, Rafaela Alexandre Saad ${ }^{[a]}$
}

\footnotetext{
[a] Pharmacy student, Pontifícia Universidade Católica do Paraná (PUCPR), Curitiba, PR - Brazil.

[b] Professor of Toxicology at Faculty of Pharmacy, Pontifícia Universidade Católica do Paraná (PUCPR), Curitiba, PR - Brazil, e-mail: sergio.f@pucpr.br
}

\begin{abstract}
The objective of this research was to evaluate, through an indirect method, the presence of anticholinesterasic substances in tobacco from cigarettes manufactured in Brazil. Organophosphate and carbamates compounds, which are used in the crops of the tobacco, are the main substances with this characteristic. From each one of the ten main cigarette labels, the tabacco had been separated and extracted anticholinesterasic substances using the method described by Leite (1980) and the n-hexane as solvent. After the preparation of the extract, of the blood was separated the plasma for the determination of the activity of butyrylcholinesterase (BChE) using the method described by Dietz et al (1973). The enzyme activity was measured in the presence of the extracts of each tobacco extract. An significative average inhibition of $20.16 \%$, $(p<0.001)$.
\end{abstract}

Keywords: Organophosphate. Carbamates tobacco. Butyrylcholinesterase.

\section{Resumo}

O objetivo deste trabalho foi avaliar, por meio de um método indireto, a presença de substâncias anticolinesterásicas no tabaco de cigarros produzidos no Brasil. Os compostos organofosforados e carbamatos, que são usados nas lavouras 
do tabaco, são as principais substâncias com essa característica. Foram analisadas as dez principais marcas de cigarros manufaturados no Brasil. Decada marca de cigarro, foi separado o tabaco e extraídas as substâncias anticolinesterásicas, seguindo um método descrito por Leite (1980) e empregando o n-hexano como solvente. Após o preparo do extrato, foi coletado sangue e separado o plasma para a determinação da atividade da butirilcolinesterase (BChE), empregando-se o método descrito por Dietz et al. (1973). A atividade enzimática foi medida na presença dos extratos de cada uma das marcas, observando-se uma significativa inibição da atividade da BChE com valores médios de 20,16\% $(p<0,001)$.

Palavras-chave: Organofosforados. Carbamatos. Tabaco. Butirilcolinesterase.

\section{Introduction}

Brazil is the most important exporter country of tobacco leaves and the second world-wide producer, in the southern of the country is located $92.7 \%$ of the national cultivated area by families who possess small properties and powerful transnational corporations that industrialize the tobacco (1).

For the production of tobacco derivatives, many toxic substances are used worldwide, such as organophosphate and carbamates compounds, both of them havebeenused asinsecticides. These substances affect the central and peripheral nervous systems, inhibiting a very important enzyme: the erythrocyte acetylcholinesterase EC 3.1.1.7 (AChE-E) (2), in human plasma there is another enzyme: butyrylcholinesterase EC 3.1.1.8 (BChE) (3) also is inhibited by the same substances and have being used as a biological marker for occupational exposure control in many countries including Brazil (4).

The mechanism of action of these compounds is associated with inhibition of brain acetylcholinesterase (AChE-B) in the nervous system. As this enzyme hydrolyzes acetylcholine, a major neurotransmitter in the central, somatic and parasympathetic nervous systems, upon AChE-B inhibition, acetylcholine released from nerve terminals accumulates and over-stimulates muscarinic and nicotinic receptors. The signs and symptoms of organophosphate and carbamate poisoning reflect those of a cholinergic crisis and include central and peripheral nervous system manifestations (5)

The chronic exposition to organophosphate and carbamate compounds is related to neurological toxicity $(6,7)$, teratogenesis $(8)$, lower sperm concentration (9).

Jin et al. (10) have described a method to detect organophosphate and carbamate substances using the acetylcholinesterase inhibition, the per- centage inhibition of enzyme activity is correlated to the pesticide concentration. Nagatani et al. (11) developed enzymatic assay involving $\mathrm{AChE}$ to detect organophosphate pesticides in food. Nanda Kumar et al. (12) and Weins and Jork (13) created thin-layer chromatography methods where the separated components were detected by enzyme inhibition.

For organophosphate and carbamate detection in many kind of samples, have been used gas and liquid chromatography methods $(14,15)$, these methods, unfortunately are too much expensive for many laboratories, so in this paper, we are describing a very simple, fast and inexpensive method to search organophosphate and carbamate compounds in tobacco from Brazilian manufactured cigarettes through inhibition of human $\mathrm{BChE}$

\section{Materials and methods}

After a research about important tobacco industries in Brazil, were tested the ten more consumed cigarettes labels in this country. The cigarettes were numerically identified and the anticholinesterasic insecticides were extracted from these samples using the method developed by Leite cited by Moraes (16).

The tobacco from each one of the labels was putted into a $150 \mathrm{~mL}$ erlenmeyer with $80 \mathrm{~mL}$ of n-hexane and shacked during 30 minutes. After that, the extract was filtered and concentrated in a $45^{\circ} \mathrm{C}$ water bath until complete evaporation of the solvent.

The butyrylcholinesterase (BChE) activity was determined by the Dietz et al. (17) method. At first, female human blood sampled heparinized was used to evaluate the BChE basal level activity. To verify weather $n$-hexane can interfere in enzyme activity, this activity was evaluated with the solvent ( $60 \mu \mathrm{L}$ of $\mathrm{n}$-hexane in $0,6 \mathrm{~mL}$ of plasma). 
Evaluation of anticholinesterasic substances in cigarettes manufactured in

In the Dietz et al. (17) method the BChE hydrolyzes the substrate (propionylthiocholine) to yield free sulfhydryl, which reacts with the color reactive (DTNB - 5,5' - dithiobis (2-nitrobenzoic acid) to yield the 5-thio-2-nitrobenzoate ion, this ion is yellow and has a useful maximum absorption at $410 \mathrm{~nm}$. The Table 1 summarizes the method.

After verify that the solvent cannotinterfere in enzyme activity, each one of the extracts were individually tested $(60 \mu \mathrm{L}$ of extract in $0,6 \mathrm{~mL}$ of plasma). The percentage inhibition from base line activity was calculated and statically tested through Student's " $t$ " test, the software BioEstat 5.0 developed by Ayres et al. (18) was used for the calculations.

\section{Results}

After the BChE basal level and solvent (n-hexane) activities had been evaluated, no difference was observed. BChE basal level activity corresponded 6,710 IU/L and BChE activity in presence of solvent (n-hexane) corresponded 6,740 IU/L.

Table 2 shows the enzymatic activities evaluated in the presence of the tobacco extracts. All the ten tested labels had inhibited, BChE activity when compared to the control (BChE basal level). The average enzymatic inhibition was $20.16 \% \pm 2,14 \%$, this inhibition magnitude is statically significant $(\mathrm{p}<0,001)$.

\section{Discussion}

The organophosphate compounds are extremely used in tobacco culture currently in Brazil (19). Viana etal. (20) cite many health problems related to chronic exposition to these substances, like neuropathy and depression. Falk et al. (21) had observed a high frequency of suicides in Venâncio Aires, a city located in Rio Grande do Sul, a Brazilian Southern State, this city's economy comes basically from the tobacco, these researchers had raised the hypothesis that this phenomenon would be related with the use of organophosphate compounds in this plantation.

In the cigarette's smoke are found more than 4,700 substances, among them are the organophosphate and carbamate compounds. Mello-da-Silva and Fruchtengarten (22) comment that the children, due the physiological characteristics and habits of their parents, are more exposed to cigarette's smoke with these compounds than adults, these researchers cite the organophosphates malathion, chlorpyriphos and diazinon and the carbamate carbaryl.

We had concluded that this method is very simple, fast and not expensive, being able to be applied for search of anticholinesterasic compounds in many kinds of samples, including tobacco, it will be useful mainly where other methods, as the gas chromatography is not available or cannot be used to control the use of these toxic compounds. The next step it will be the standardization of the method.

Table 1 - Protocol for the procedure

\begin{tabular}{|c|c|c|}
\hline \multirow[b]{2}{*}{ Reactives } & \multicolumn{2}{|c|}{ Tube (mL) } \\
\hline & Blank & Test \\
\hline Substrate (propionylthiocholine iodide) $45 \mathrm{mmol} / \mathrm{L}$ & 0,5 & 0,5 \\
\hline Color reagent (DTNB) 0,423 mmol/L & 1,5 & 1,5 \\
\hline \multicolumn{3}{|l|}{ Warm to $37^{\circ} \mathrm{C}$ ( 5 minutes) } \\
\hline Serum* & - & 0,01 \\
\hline \multicolumn{3}{|l|}{ Incubation for $2 \mathrm{~min}$ and 30 seconds at $37^{\circ} \mathrm{C}$} \\
\hline Inhibitor solution (quinidine sulfate) $0,5 \%$ & 1,5 & 1,5 \\
\hline Serum* & 0,01 & - \\
\hline
\end{tabular}

Note: $*=$ For basal level activity is used serum without n-hexane or extract. 
Table 2 - The BChE activity was lower than base line activity after addition of the extracts $(\mathrm{p}<$ $0,001)$, this shows the anti-cholinesterasic effect of the extracts

\begin{tabular}{lcc}
\hline Reactives & Blank & Test \\
\hline 1 & $5,690 \mathrm{IU} / \mathrm{L}$ & 15,20 \\
2 & $4,630 \mathrm{IU} / \mathrm{L}$ & 31,00 \\
3 & $5,980 \mathrm{IU} / \mathrm{L}$ & 10,88 \\
4 & $5,510 \mathrm{IU} / \mathrm{L}$ & 17,88 \\
5 & $5,250 \mathrm{IU} / \mathrm{L}$ & 21,76 \\
6 & $4,980 \mathrm{IU} / \mathrm{L}$ & 25,78 \\
7 & $5,070 \mathrm{IU} / \mathrm{L}$ & 24,44 \\
8 & $4,950 \mathrm{IU} / \mathrm{L}$ & 26,23 \\
9 & $5,540 \mathrm{IU} / \mathrm{L}$ & 17,44 \\
10 & $5,970 \mathrm{IU} / \mathrm{L}$ & 11,03 \\
\hline
\end{tabular}

\section{References}

1. Almeida GEG. Fumo: servidão moderna e violações de direitos humanos. Curitiba: Terra de Direitos; 2005. p. 25.

2. Slotkin TA. Cholinergic systems in brain development and disruption by neurotoxicants: nicotine, environmental tobacco smoke, organophosphates. Toxicol Appl Pharmacol. 2004;198(2):132-51.

3. Li B, Sedlacek M, Manobaran I, Boopathy R, Duysen EG, Masson P, et al. Butyrylcholinesterase, paraoxonase, and albumin esterase, but not carboxylesterase, are present in human plasma. Biochem Pharmacol. 2005;70(11):1673-84.

4. Brasil, Ministério do Trabalho e do Emprego, Norma Regulamentadora Número 7, Programa de Controle Médico de Saúde Ocupacional, NR-7. Diário Oficial da União [acesso 25 jul. 1978]. Disponível em: http:// www.mte.gov.br/legislacao/normas_regulamenta DORAS/nr_07_at.pdf.

5. Oga S, Camargo MMA, Batuistuzzo JAO. Fundamentos de Toxicologia. 3a ed. São Paulo: Atheneu; 2008.

6. Ames RG, Steenland K, Jenkins B, Chrislip D, Russo J. Chronic neurologic sequelae to cholinesterase inhibition among agricultural pesticide applicators. Arch Environ Health. 1995;50(6):440-4.
7. Slotkin TA, Tate CA, Ryde IT, Levin ED, Seidler FJ. Organophosphate insecticides target the serotonergic system in developing rat brain regions: disparate effects of diazinon and parathion at doses spanning the threshold for cholinesterase inhibition. Environ Health Perspect. 2006;114(10):1542-46.

8. Qiao D, Seidler FJ, Slotkin TA. Developmental neurotoxicity of chlorpirifos modeled in vitro comparative effects of metabolites and other cholinesterasic inhibitors on DNA synthesis in PC12 and C6 cells. Environ Health Perspect. 2001;109(9):909-13.

9. PerryMJ, Venners SA, BarrDB, XuX. Environmental pyrethroid and organophosphorus insecticide exposures and sperm concentration. Reprod Toxicol. 2007; 23(1):113-8.

10. Jin S, Xu Z, Chen J, Liang X, Wu Y, Qian X. Determination of organophosphate and carbamate pesticides based on enzyme inhibition using a $\mathrm{pH}$-sensitive fluorescence probe. Analytica Chimica Acta. 2004; 523(1):117-23.

11. Nagatani N, Takeuchi A, Hossain MA, Yuhi T, Endo T, Kerman K, et al. Rapid and sensitive visual detection of residual pesticides in food using acetylcholinesterase-based disposable membrane chips. Food Control. 2007;18(8):914-20.

12. Nanda Kumar NV, Visweswariah K, Majumder SK. Thin layer chromatography of parathion as paraoxon with cholinesterase inhibition detection. J Assoc Off Anal Chem. 1976;59(3):641-3.

13. Weins $\mathrm{C}$, Jork $\mathrm{H}$. Toxicological evaluation of harmful substances by in situ enzymatic and biological detection in high-performance thin-layer chromatography. J Chromatogr A. 1996;750(1-2):403-7.

14. You J, Weston DP, Lydy MJ. A sonication extration method for the analysis of pirethroid, organophosphate, and organochlorine pesticides from sediment by gas chromatography with electron capture detection. Arch Environ Contam Toxicol. 2004;47(2): 141-7.

15. Borba da Cunha AC, López de Alda MJ, Barceló D, Pizzolato TM, dos Santos JH. Multianalyte determination of different classes of pesticides (acidic, triazines, phenyl ureas, anilines, organophosphates, molinate and propanil) by liquid chromatographyelectrospray-tandem mass spectrometry. Anal Bioanal Chem. 2004;378(4):940-54. 
16. Moraes ECF, Sznelwar RB, Fernicola NAGG. Manual de toxicologia analítica. São Paulo: Roca; 1991. p. 106-7.

17. Dietz AA, Rubinstein HM, Lubrano T. Colorimetric determination of serum cholinesterase and its genetic variants by propionylthiocholine - dithiobis (nitro benzoic acid) procedure. Clin Chem. 1973;19(11):1309-13.

18. Ayres M, Ayres Jr M, Ayres DL, Santos AS. BioEstat 5.0: aplicações estatísticas nas áreas das ciências biológicas e médicas. Brasília: Sociedade Civil Mamirauá; 2007. [acesso 21 jun. 2009]. Disponível em: http:// www.mamiraua.org.br/download.

19. Bellini N. Cultura do veneno. Revista Problemas Brasileiros. 2004[acesso 22 jun. 2009];362. Disponível em: http://www.sescsp.org.br/sesc/revistas_ sesc/pb/artigo.cfm?Edicao_Id=182\&breadcrumb= 1\&Artigo_ID=2753\&IDCategoria=2797\&reftype $=1$.

20. Viana EMO, Artal FJC, Almeida AC. Polineuropatia desmielinizante crônica por organafosforados. [internet] Primer Congreso Virtual Iberoamericano de Neurologia, 1998 [acesso 11 set. 2009]. Disponível em: http://neurologia.rediris.es/congreso-1/ comunicaciones/c-26.html.
21. FalkJW, Carvalho LA, Silva LR, Pinheiro S. Suicídio e doença mental em Venâncio Aires - RS, conseqüência do uso de agrotóxicos organofosforados? Relatório Preliminar de Pesquisa, Comissão de Cidadania e Direitos Humanos da Assembléia Legislativa do Rio Grande do Sul, 1996 [acesso 11 set. 2009]. Disponível em: http://galileu.globo.com/edic/133/agro2.doc.

22. Mello-da-Silva CA, Fruchtengarten L. Riscos químicos ambientais à saúde da criança. J Pediatr. 2005;81 (5 Supl.):S205-11.
Received: 02/17/2009

Recebido: 17/02/2009

Approved: 10/14/2009

Aprovado: 14/10/2009 